ORIGINAL ARTICLE

\title{
FREQUENCY OF ANTI-Toxocara spp. ANTIBODIES IN INDIVIDUALS ATTENDED BY THE CENTRO DE SALUD FAMILIAR AND ENVIRONMENTAL CONTAMINATION WITH ToXocara canis EGGS IN DOG FECES, IN THE COASTAL NIEBLA TOWN, CHILE
}

\begin{abstract}
SUMMARY
The frequency of anti-Toxocara spp. antibodies in individuals attended by the Centro de Salud Familiar in the coastal Niebla town, Chile, was related to the host and to environmental factors. IgG anti- Toxocara antibodies were detected with a commercial ELISA kit (SCIMEDX Corporation, USA). Samples with undetermined absorbance values were subjected to an additional ELISA standardized by the Instituto de Salud Pública, Chilean Health Ministry, a commercial ELISA (NOVATEC, Germany), and a commercial Western blot kit (LDBio Diagnostics, France). Hematological exams were performed using an automated blood counter and blood smears. Dog feces were collected from the ground along the main road in Niebla, including rural and urban locations. Ninety (25.4\%) of the 355 examined individuals were positive by the ELISA test. The frequency of anti-Toxocara antibodies and the infection risk were significantly higher $(p<0.05)$ among those individuals $\geq 40$ years old with respect to the $20-39$ years old group, in individuals from rural locations, those who did not have a safe drinking water supply in the house or who presented blood eosinophilia. The proportion of positive samples of dog feces and the mean number of Toxocara canis eggs/g of feces in urban and rural areas were similar $(p>0.05)$.
\end{abstract}

KEYWORDS: Seroprevalence; Human toxocariasis; Environmental contamination; Eosinophilia.

\section{INTRODUCTION}

Toxocariasis is a neglected worldwide distributed zoonosis caused by the third-stage larva (L3) of Toxocara canis and Toxocara cati nematodes whose definitive hosts are the domestic dog and cat, respectively. Eggs eliminated by $T$. canis females are expelled with the dog feces. The infective L3 larvae develop in eggs in the soil between $12{ }^{\circ} \mathrm{C}$ and $32{ }^{\circ} \mathrm{C}$, with a relative humidity close to $85 \%$. Eggs are viable for years and are found in $6.6 \%$ to $95 \%$ of soil samples from different countries ${ }^{1}$.

Transmission occurs predominantly by ingestion of infective eggs present in soil (onicophagy, geophagy) or less frequently by consumption of contaminated raw vegetables, fruits or water. Other possible route of Toxocara transmission is the ingestion of larvae from undercooked tissues of paratenic hosts (birds, ruminants or pigs). Human can also be infected through the direct contact with eggs containing infective larvae present in dog hair ${ }^{2}$. Hatched L3 larvae penetrate the intestinal mucosa and enter the mesenteric vessels to reach the liver, lungs, heart, eyes, and the central nervous system, inducing the formation of granulomas ${ }^{3}$.

Diagnosis of human toxocariasis is based on clinical, epidemiological, and serological test data; the latter mainly through the detection of antiT. canis/T. cati antibodies by the enzyme linked immunosorbent assay (ELISA) ${ }^{1}$. The combined use of ELISA to detect IgG, with detection of excretion-secretion antigens and Western blot assays constitute a good diagnostic option due to their sensibilities and specificities; even when the application of these tests do not differentiate between an active disease and a past infection ${ }^{4}$.

Different clinical forms are described for human toxocariasis: visceral larva migrans (VLM), ocular larva migrans (OLM), neurological toxocariasis (NT) and covert or common toxocariasis ${ }^{5,6}$. In Chile, OLM has been identified in 31 patients with ages ranging from 4 to 45 years $\mathrm{old}^{7}$. In addition, one out of 175 children with positive serology also develops retinal granuloma and visual loss ${ }^{8}$. VLM has been described in 129 children with serological evidence associated with lung, hepatic, ocular, neurological or skin problems ${ }^{9,10}$. In addition, a case of NT associated with high eosinophilia and positive serology was diagnosed in a 61 year old man ${ }^{11}$.

Transmission and risk factors of toxocariasis vary between different geographical localities, and they have been associated with poverty, low 


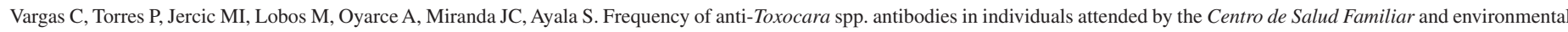
contamination with Toxocara canis eggs in dog feces, in the coastal Niebla town, Chile. Rev Inst Med Trop Sao Paulo. 2016;58:62.

education level, and lack of control or treatment of definitive hosts. All the above mentioned factors favor contamination which is reinforced by environmental conditions (light, temperature, humidity, $\mathrm{pH}$, vegetation), and also the development, survival and availability of parasite eggs ${ }^{12}$. Seroprevalence of human toxocariasis varies between $1.6 \%$ and $92.8 \%$ in different countries ${ }^{1}$. Great variability are also described, from $3.7 \%$ and $40 \%$ among localities of a same country ${ }^{13}$. In Chile, seroprevalence varies between $1.3 \%$ and $15.6 \%$ in blood donors ${ }^{14,15}$. Toxocara canis and T. cati prevalences are from $10.7 \%$ to $19 \%{ }^{16,17,18}$ and $65.1 \%$ to $70 \%{ }^{16,19}$ in dogs and cats, respectively, in the region of Valdivia.

Although some risk factors have been identified for toxocariasis, there is still much inconsistent information ${ }^{1}$. For example, there is a wide age range leading to the conclusion that there is a higher prevalence in some age groups ${ }^{20,21}$. In other studies, no association between seroprevalence and age has been found ${ }^{20,22}$. Gender does not seem to be a factor associated with human toxocariasis ${ }^{23}$. However, some authors report the opposite ${ }^{24}$. Toxocariasis tends to be more prevalent in rural areas than in urban ones ${ }^{23,25}$. Higher eroprevalences have been associated with the tenancy of dogs and $\mathrm{cats}^{26}$, particularly regarding veterinarians and those in charge of pets ${ }^{27}$. Other authors have not found this association ${ }^{28}$. Some reports associate poor sanitation with higher seroprevalences of toxocariasis ${ }^{20}$. Several authors either associate ${ }^{24,27}$ or do not associate ${ }^{22}$ higher seroprevalences with eosinophilia. In the same way, leukocytosis has been associated ${ }^{28}$ or not $^{20}$ with higher seroprevalences. Hemoglobin values have not apparently been associated with VLM and OLM ${ }^{27,10}$.

The aim of this study is to determine the frequency of anti-Toxocara spp. antibodies in individuals attended by the Centro de salud familiar in the coastal Niebla town and associate it with clinical, laboratory and environmental data, including the detection of Toxocara eggs in dog feces.

\section{MATERIALS AND METHODS}

\section{Study area and human participants}

The coastal area of Niebla (Fig. 1), located $15 \mathrm{~km}$ from the city of Valdivia (39 $48^{\prime} 30^{\prime \prime} \mathrm{S}$ and $73^{\circ} 14^{\prime} 30^{\prime \prime} \mathrm{W}$ ), has a population of 2,202 and 1,376 inhabitants in the urban and rural areas, respectively ${ }^{29}$. The zone has a mean annual temperature of $12{ }^{\circ} \mathrm{C}$ and a relative humidity of $88.7 \%$. The study considered individuals who attended the Centro de Salud Familiar (CESFAM) in Niebla to perform a complete blood count, between September 2011 and January 2012. The study was approved by the Ethics Committee in Research, Valdivia Health Service, and Chilean Health Ministry. Recruited people consented in performing the ELISA test for toxocariasis. From the total of 490 people invited to participate in the study, 355 agreed and completed a survey containing their names, age, area where they lived (urban or rural), the ownership of pets (dogs or cats), if they had a yard or a garden, vegetables in the garden, and type of water supply in the house. The 355 participants are representative of people living in urban and rural areas of the Niebla coast who have a limited access to laboratory tests such as the ELISA to detect antiToxocara antibodies due to the high cost. All the participants received the ELISA results. The reasons for requesting the blood count were recorded using the Omega 300 system. The distribution of the study participants according to age, gender, and location is shown in Table 1 . The age of participants varied from 9 months to 90 years old.

\section{Laboratory methods in humans}

A blood sample from each person was obtained through venous puncture. Samples collected in EDTA tubes were used to prepare blood smears stained with May Grunwald-Giemsa, and analyzed by a hematological counter (Sysmex XT-1800i, Kobe, Japan) at the Central Laboratory of the Hospital Base in Valdivia. Results were obtained using the OMEGA 3000 information system at the Hematological Unit of the School of Medicine, Austral University of Chile. Anemia was determined according to hemoglobin values ${ }^{30}$. Eosinophilia was considered when the number of eosinophils surpassed $4 \%$ of the total white cell count, in most cases when it exceeded 500cells $/ \mu L^{31}$. Afterwards, EDTA samples were centrifuged at 1,200 g for $10 \mathrm{~min}$; plasma samples were kept frozen in Eppendorf tubes at $-20^{\circ} \mathrm{C}$.

IgG anti-Toxocara canis/cati antibodies were detected by means of an ELISA kit (SCIMEDX Corporation, New Jersey, USA) at the Instituto de Salud Pública (ISP), Chilean Health Ministry. The ISP validated the kit using the Clinical and Laboratory Standard Institute guides $\mathrm{N}^{\circ}$ EP12-A2 $2^{32}$ and EP15-A2 ${ }^{33}$. The obtained sensitivity of $91.7 \%$ and the specificity of $80 \%$ fulfilled the verification requirements recommended by the manufacturer (sensitivity of $93.3 \%$ and specificity of $87.5 \%$ ). To determine the specificity, the commercial kit was applied to serum samples with confirmed diagnosis of hydatidosis, fasciolosis, trichinellosis, cisticercosis, and autoimmune diseases. Absorbance readings, $\mathrm{A}_{462}>0.350 \mathrm{OD}$ units were considered as positive reactions, while $\mathrm{A}_{462}<0.350$ OD units and $\mathrm{A}_{462}=0.250-0.350$ OD units were considered as negative and undetermined reactions, respectively. At ISP, undetermined samples underwent additional serological testing: an "in house" standardized anti-IgG ELISA (ISP) and a commercial anti-IgG ELISA (NOVATEC, Dietzenbach, Germany). The positive samples had the results confirmed by a commercial Western blot kit (LDBio Diagnostics, Lyon, France). Samples presenting with two or more polypeptide bands of lower molecular weight (40,30, 25, and 14 kDA), were considered as positive. The "in house" IgG ELISA assay was evaluated with respect to sensitivity, specificity and precision parameters using the Clinical and Laboratory Standard Institute Guides (CLSI), $\mathrm{EP} 12-\mathrm{A} 2^{32}$ and EP15-A2 $2^{33}$

\section{Fecal dog samples collection and laboratory methods}

In March 2012, samples of dog feces were collected from the ground along the main road in Niebla, including about $9 \mathrm{~km}$ of rural and urban locations (Fig.1). Samples were collected, manually, using double polyethylene bags by two people through a visual inspection of the main road path. At the laboratory, each sample was weighed, homogenized and kept at $4{ }^{\circ} \mathrm{C}$. Five grams were taken from each sample and fixed in $10 \mathrm{~mL}$ of formol-saline to perform the qualitative Telemann modified method (TMM) in combination with a floating method (FM) which uses $70 \mathrm{~g}$ of zinc sulphate in $100 \mathrm{~mL}$ of distilled water ${ }^{19}$. The combination of TPM and FM offers a greater efficacy in the detection of Toxocara spp. eggs, in comparison with the techniques applied independently ${ }^{18}$. Regarding the Knight et al. quantitative method (KM) ${ }^{34}$, feces from homogenized samples were added to a conical calibrated centrifuge tube containing 7 $\mathrm{mL}$ of formol-saline to complete $8 \mathrm{~mL}$. To find $T$. canis eggs using the combined TMM and FM method, two microscopic preparations of the sediment and one preparation of FM were examined. For the KM, all the sediment was examined in microscopic preparations ${ }^{34}$. All preparations 


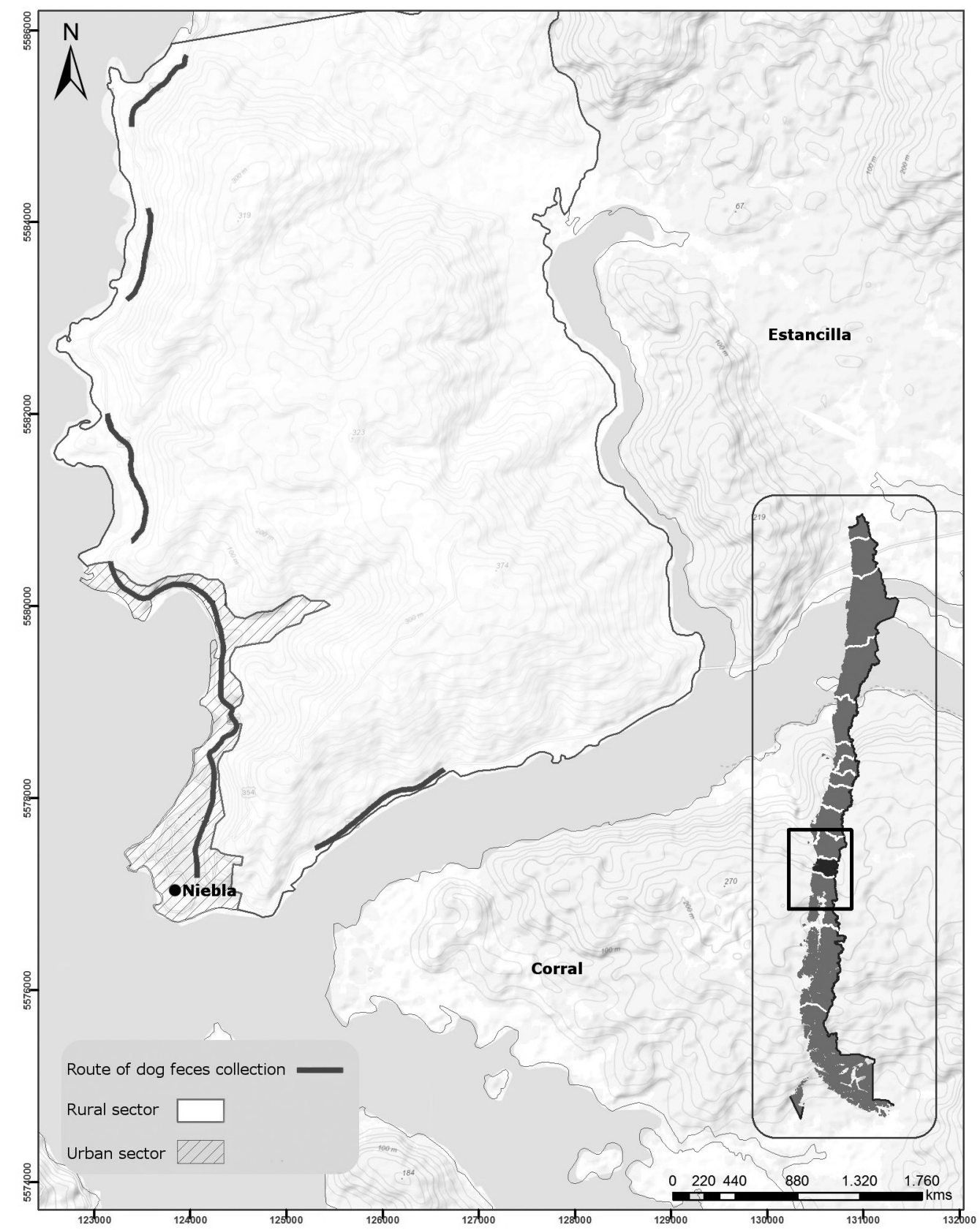

Fig. 1 - Route of dog feces collection from the ground and rural and urban sectors in the Niebla coastal locality, Chile.

using 22 x $22 \mathrm{~mm}$ cover glass were examined under a light microscope $(100 \mathrm{x})$. Results of the KM method were expressed as the number of eggs/g of feces.

\section{Statistical analysis}

Seroprevalence corresponds to the number of seropositive people/ number of people examined x 100.To compare the seroprevalences, the Pearson's chi-square with the Yates's correction was applied. When pairs of samples presented expected frequencies $\leq 5$, the Fisher's exact test was used $^{35}$. The U Mann-Whitney test was used to compare the eggs mean/g of feces ${ }^{35}$. For all the tests, results were considered significant at $p<0.05$. Odds ratios (OR) and $95 \%$ confidence intervals (CI) were calculated with the free software "VassarStat available at http://vassarstats.net/textbook/ index.html. When odds ratios and confidence intervals values were $>1$ they were considered significant.

\section{RESULTS}

Ninety (25.4\%) of the 355 participants were positive for IgG antiToxocara spp. antibodies by the ELISA test; their location is shown in Figure 1. Twenty serum samples were undetermined but 15 of them 


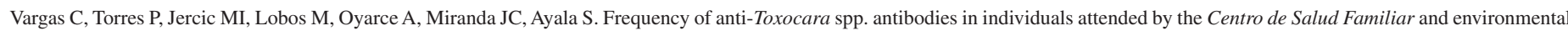
contamination with Toxocara canis eggs in dog feces, in the coastal Niebla town, Chile. Rev Inst Med Trop Sao Paulo. $2016 ; 58: 62$.

Table 1

Seropositivity of IgG anti-Toxocara spp. antibodies according to host and environmental factors, in 355 people attended at Centro de la Salud Familiar in the coastal locality of Niebla, Chile

\begin{tabular}{|c|c|c|c|}
\hline \multirow[b]{2}{*}{ Factors } & \multicolumn{3}{|c|}{ Seropositivity } \\
\hline & $\begin{array}{c}\mathrm{N}^{\circ} \text { of positive samples/ex- } \\
\text { amined (percentage) }\end{array}$ & $\begin{array}{c}\text { Chi-square or Fisher test } \\
p \text {-value }\end{array}$ & Odds ratios $(95 \% \mathrm{CI})$ \\
\hline \multicolumn{4}{|l|}{ Age groups (years) } \\
\hline$\leq 19$ (a) & $17 / 77(22.1)$ & 0.0266 & a with b $0.71(0.33-1.53)$ \\
\hline $20-39$ (b) & $15 / 90(16.7)$ & & a with c $1.57(0.85-2.93)$ \\
\hline$\geq 40$ (c) & $58 / 188(30.9)$ & & b with c $2.23(1.18-4.21)$ \\
\hline \multicolumn{4}{|l|}{ Gender } \\
\hline Male & $33 / 110(30.0)$ & 0.2236 & $0.71(0.43-1.17)$ \\
\hline Female & $57 / 245(23.3)$ & & \\
\hline \multicolumn{4}{|l|}{ Origin } \\
\hline Rural & $44 / 140(31.4)$ & 0.0456 & $1.68(1.04-2.73)$ \\
\hline Urban & $46 / 215(21.4)$ & & \\
\hline \multicolumn{4}{|l|}{ Presence of yard/ garden } \\
\hline Yes & $86 / 342(25.1)$ & 0.7454 & $1.32(0.40-4.41)$ \\
\hline No & 4/13 (30.8) & & \\
\hline \multicolumn{4}{|c|}{ Presence of vegetable in the garden } \\
\hline Yes & $35 / 114(30.7)$ & 0.1435 & $0.67(0.41-1.09)$ \\
\hline No & $55 / 241(22.8)$ & & \\
\hline \multicolumn{4}{|l|}{ Ownership of dogs/ cats } \\
\hline Yes & $80 / 289(27.7)$ & 0.0506 & $0.47(0.23-0.96)$ \\
\hline No & $10 / 66(15.1)$ & & \\
\hline \multicolumn{4}{|l|}{ Presence of safe drinking water } \\
\hline Yes & $61 / 272(22.4)$ & 0.0316 & $1.86(1.09-3.17)$ \\
\hline $\mathrm{No}^{1}$ & $29 / 83(35)$ & & \\
\hline \multicolumn{4}{|l|}{ Anemia } \\
\hline Yes & $2 / 9(22.2)$ & 1.0000 & $1.19(0.24-5.85)$ \\
\hline No & $88 / 346(25.4)$ & & \\
\hline \multicolumn{4}{|l|}{ Leukocytosis } \\
\hline Yes & $5 / 17(29.4)$ & 0.7753 & $0.81(0.28-2.36)$ \\
\hline No & $85 / 338(25.1)$ & & \\
\hline \multicolumn{4}{|l|}{ Absolute eosinophilia } \\
\hline Yes & $15 / 30(50.0)$ & 0.0025 & $0.3(0.14-0.64)$ \\
\hline No & $75 / 325(23.1)$ & & \\
\hline \multicolumn{4}{|l|}{ Relative eosinophilia } \\
\hline Yes & $31 / 75(41.3)$ & 0.0006 & $2.64(1.53-4.54)$ \\
\hline No & $59 / 280(21.1)$ & & \\
\hline \multicolumn{4}{|c|}{ Most frequent reasons for requesting the blood count } \\
\hline Health control (a) & $27 / 81(33.3)$ & 0.7523 & \\
\hline Diabetes (b) & $11 / 38(28.9)$ & & a with b $1.23(0.53-2.84)$ \\
\hline Dyslipidemia (c) & $14 / 54(25.9)$ & & a with c $1.43(0.67-3.1)$ \\
\hline High blood pressure (d) & $27 / 80(33.8)$ & & a with d $0.98(0.51-1.89)$ \\
\hline
\end{tabular}

${ }^{1}$ Included water from spring, borehole or stream 


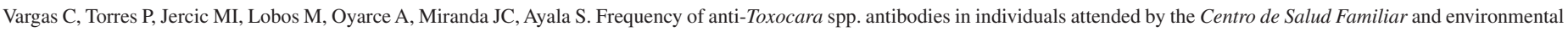
contamination with Toxocara canis eggs in dog feces, in the coastal Niebla town, Chile. Rev Inst Med Trop Sao Paulo. $2016 ; 58: 62$.

proved definitively to be positive when the three additional tests were performed. The proportion of individuals with anti-Toxocara spp. antibodies was significantly higher $(p<0.05)$ in people of different age groups, in all the individuals living in rural areas and among those who did not have a safe drinking water supply in the house (Table 1).

Younger age groups $(\leq 40$ years old) did not show statistical significant differences $(p>0.05)$ (Table 1). However, the proportion of individuals with anti-Toxocara spp. antibodies was significantly lower $(p<0.05)$ in the age group of 20-39 years old with respect to the age group $\geq 40$ years old (Table 2 ). The risk for those $\geq 40$ years old was significantly increased (OR 2.23; 95\% CI: 1.18 - 4.21) with respect to those with 20-39 years old (Table 1). The infection risk was higher for individuals living in rural areas (OR 1.68; 95\% CI: $1.04-2.73$ ) and among those who did not have safe drinking water supplies (OR 1.86; $95 \%$ CI: 1.09 - 3.17). The proportion of people with anti-Toxocara spp. antibodies of different genders did not show significant differences $(p>$ 0.05 ) and the risk did not show significant association (OR $0.71 ; 95 \%$ CI: 0.43 - 1.17) (Table 1).

The existence of a yard, garden or vegetables in the garden of the house of the people surveyed as well as the ownership of dogs or cats was not associated with a significantly higher seroprevalence or risk (Table 2 ). The same was true for the proportion of environmental samples of dog feces with Toxocara eggs and their eggs mean/g feces from rural and urban areas (Table 2).

The frequency of anti-Toxocara spp. antibodies was significantly higher $(p<0.05)$ among individuals with relative or absolute eosinophilia. However, in individuals with or without anemia or leukocytosis it was similar $(p>0.05)$ (Table 1$)$. The risk was significantly higher for those individuals with relative eosinophilia (OR 2.64; 95\% CI: 1.53 - 4.54).

There was no significant difference between the most frequent reasons (health control, diabetes, dyslipidemia and high blood pressure) for requesting a blood count and the Toxocara positivity and negativity $(p>0.05)$ (Table 1). Also, the infection risk did not show a significant association among individuals who performed the blood exam for health control due to diabetes, dyslipidemia and high blood pressure (Table 1).

\section{DISCUSSION}

The frequency of anti-Toxocara spp. antibodies in individuals attended by the Centro de Salud Familiar in Niebla surpassed the values estimated by Herskovic \& Astorga ${ }^{14}$ in blood donors from three regions in Chile (1.3\% to $15.6 \%$ ); in the population of Robinson Crusoe Island $(3.8 \%)^{36}$, and in blood donors $(5.3 \%)$ from the city of Valdivia ${ }^{15}$.

In a review of toxocariasis in Latin America ${ }^{37}$, the seroprevalence in the human populations of different age groups varied between $22.1 \%$ and $31.6 \%$ in Argentina, $27 \%$ and $42 \%$ in Bolivia, $47.5 \%$ in Colombia, 5.2\% in Cuba, $7.3 \%$ and $27.9 \%$ in Peru, $6.5 \%$ in Puerto Rico, and $34.9 \%$ in indigenous populations in Venezuela.

The similarity of Toxocara spp. infection in the two younger age groups and the significant higher frequency of anti- Toxocara spp. antibodies and the higher risk for individuals $\geq 40$ years old with respect to the 20-39 years old group suggests that L3 larvae remain in the tissues, and that recurrent reinfections maintain the level of circulating antibodies in the affected population. The survival of the parasite in the tissues is also favored by the mechanisms that L3 larvae use to evade the immunological response ${ }^{38}$. In Valdivia, Navarrete \& Rojas ${ }^{15}$ did not find significant differences in the seroprevalence of different age groups of blood donors. In Colombia, Agudelo et al ${ }^{39}$ found higher seroprevalences in age groups from 10-39 in a population of age varying from months to 70 years old. Rubinsky-Elefant et al..$^{40}$ found a higher seroprevalence in people from 5 to 14 years old in comparison with those from 15 to 90 years old in the Amazonian region of Brazil. In Bolivia ${ }^{21}$ and Brazil ${ }^{20}$ seroprevalence was similar in different age groups, in populations from two to 85 and from 3 months to 80 years old, respectively.

In Niebla, the frequency of anti-Toxocara spp. antibodies and the infection risk was similar in different gender groups. These data is in agreement with those from other Chilean authors ${ }^{15}$ and in other countries ${ }^{21,23,41}$. However, some other studies reported higher seroprevalences in males ${ }^{1,24}$ than in females ${ }^{39}$. The latter has been associated with a more intense exposure due to working activities ${ }^{24}$ in those with more contact with soil, working in agriculture or cattle rising.

Results suggest that the level of contamination and the risk of transmission of human toxocariasis in rural and urban areas would be similar since the proportion of positive dog feces samples, taken directly from the soil, and the eggs mean/g of feces did not present significant differences between these areas. Nevertheless, the frequency of anti-Toxocara spp. antibodies and the risk of infection were higher in individuals from rural areas. Gawor et al. ${ }^{42}$ concluded that in Poland, the proportion of soil samples from rural and urban homes contaminated with Toxocara eggs was similar. The proportion of dog feces samples with Toxocara eggs was similar (13.5\%) to previous data from the city of Valdivia ${ }^{16,17,18,43}$. In Brazil, Negri et al ${ }^{44}$ did not find significant differences in the seroprevalence of people from rural or urban areas. Studies in the

Table 2

Proportion of dog feces positive for Toxocara eggs collected from the ground and the mean of the number/g of sample in rural and urban areas in the coastal locality of Niebla, Chile

\begin{tabular}{|c|c|c|c|}
\hline \multirow{2}{*}{ Descriptors } & \multicolumn{2}{|c|}{ Areas } & \multirow{2}{*}{$p$-value } \\
\hline & Rural & Urban & \\
\hline Positive/examined samples (percentage) & $12 / 78(15.4)$ & $12 / 77(15.6)$ & $0.8536^{1}$ \\
\hline Mean of eggs/g in examined samples (minimum-maximum) & $11.3(0-646)$ & $8.4(0-513)$ & $0.9840^{2}$ \\
\hline
\end{tabular}

${ }^{1}$ Chi-square test. ${ }^{2} \mathrm{U}$ Mann-Whitney test 
Vargas C, Torres P, Jercic MI, Lobos M, Oyarce A, Miranda JC, Ayala S. Frequency of anti-Toxocara spp. antibodies in individuals attended by the Centro de Salud Familiar and environmental contamination with Toxocara canis eggs in dog feces, in the coastal Niebla town, Chile. Rev Inst Med Trop Sao Paulo. 2016;58:62.

U.S.A. ${ }^{25}$, and Turkey $^{23}$ showed that seroprevalences of human toxocariasis were significantly higher in rural areas.

The existence of a yard, garden or vegetable in the garden, in the house, as well as having pets was not associated with seropositivity and infection risk in individuals of Niebla. Roldán et al. ${ }^{28}$ reported an association between individuals that were seropositive for Toxocara and the existence of gardens. Other studies in Brazil ${ }^{20}$ and Colombia ${ }^{39}$ have shown that there is no association between seroprevalence and having pets. However, there are also studies that have shown the opposite in Argentina $^{22}$, Brazil $^{26}$, Chile ${ }^{45}$, Colombia ${ }^{46}$, and Peru ${ }^{24}$.

The prevalence of toxocariasis and the infection risk in Niebla were higher among individuals that did not have safe drinking water supplies in their homes. This suggests that the water consumed from springs, boreholes or streams are potentially contaminated with Toxocara eggs or that food washed with these water sources could represent a transmission risk, coinciding with a study performed in Colombia ${ }^{46}$. Anaruma-Filho et al..$^{20}$ concluded that individuals who filtered drinking water before consumption showed a significantly lower frequency of toxocariasis, compared with those who did not treat drinking water.

The frequency of anti-Toxocara spp. antibodies in Niebla was significantly higher in people with eosinophilia, confirming the results obtained in Argentina ${ }^{22}$, Brazil ${ }^{41}$ and Peru $^{24}$. However, the frequency of antibodies was not associated with the presence of anemia or leukocytosis, corroborating other studies ${ }^{20,24,27,41}$.

As a conclusion, the frequency of anti-Toxocara spp. antibodies and the infection risk was significantly higher among individuals $\geq 40$ years old with respect to the 29-39 years group, in those living in rural areas, and also among those that did not have safe drinking water supplies at home or who presented blood eosinophilia.

\section{ACKNOWLEDGEMENTS}

This research was partially funded by the Parasites Diversity and Zoonosis Transmitted by Aquatic Organisms Program. Dirección de Investigación y Desarrollo (DID N ${ }^{\circ}$ I2010-02). Universidad Austral de Chile. The authors are indebted to Claire Evans for the English revision of the manuscript.

\section{REFERENCES}

1. Rubinsky-Elefant G, Hirata CE, Yamamoto JH, Ferreira MU. Human toxocariasis: diagnosis, worldwide seroprevalences and clinical expression of the systemic and ocular forms. Ann Trop Med Parasitol. 2010;104:3-23.

2. Overgaauw PA, van Knapen F. Veterinary and public health aspects of Toxocara spp. Vet Parasitol. 2013;193:398-403.

3. Barriga OO. A critical look at the importance, prevalence and control of toxocariasis and the possibilities of immunological control. Vet Parasitol. 1988;29:195-234

4. Fillaux J, Magnaval JF. Laboratory diagnosis of human toxocariasis. Vet Parasitol. 2013;193:327-36

5. Fan CK, Liao CW, Cheng YC. Factors affecting disease manifestation of toxocarosis in humans: genetics and environment. Vet Parasitol. 2013;193:342-52.
6. Smith H, Noordin R. Diagnostic limitations and future trends in the serodiagnosis of human toxocariasis. In: Holland CV, Smith HV, editors. Toxocara: the enigmatic parasite. Wallingford: CABI; 2006. p.89-112.

7. Sapunar J, Verdaguer J, Zenteno J, Zenteno E. Larva migrans ocular por Toxocara: analisis de 31 casos. Parasitol Día. 1989;13:21-33.

8. Sánchez JE, López JP, González M, Villaseca E, Manieu D, Roizen A, et al. Detección de lesiones oculares en niños seropositivos para Toxocara canis. Rev Chil Infectol. 2011;28:431-4.

9. Noemí I, Schuh W, Herskovic P, Ríos E, Cerva L, Torres MT, et al. Larva migrans visceral en niños. Rev Chil Pediatr. 1984;55:244-8.

10. Noemí I, Viovy A, Cerva JL, Gottlieb B, Roncone E, Quera R, et al. Perfil clínico de la toxocariasis en pediatría. Parasitol Día. 1992;16:91-7.

11. Ardiles A, Chanqueo L, Reyes V, Araya L. Toxocariasis en adulto manifestada como síndrome hipereosinofílico con compromiso neurológico predominante: caso clínico. Rev Med Chil. 2001;129:780-5

12. Macpherson $\mathrm{CN}$. The epidemiology and public health importance of toxocariasis: a zoonosis of global importance. Int J Parasitol. 2013;43:999-1008.

13. Chieffi PP, Santos SV, Queiroz ML, Lescano SA. Human toxocariasis: contribution by Brazilian researchers. Rev Inst Med Trop Sao Paulo. 2009;51:301-8.

14. Herskovic P, Astorga B. Toxocariasis humana en Chile. Rev Med Chil. 1985;113:18-21.

15. Navarrete N, Rojas E. Seroprevalencia de toxocarosis en donantes de sangre. Arch Med Vet. 1998;30:153-6.

16. Torres P, Franjola R, Pérez J, Auad S, Hermosilla C, Flores L, et al. Geohelmintosis intestinales en el hombre y animales domésticos de sectores ribereños de la cuenca del río Valdivia, Chile. Bol Chil Parasitol. 1995;50:57-66.

17. Torres P, Hauser M, Santibañez J, Marín F, Gesche W, Montefusco A. Búsqueda de Diphyllobothrium y otros parásitos intestinales en la población humana y carnívoros domésticos del sector del Lago Calafquén, Chile. Bol Chil Parasitol. 1980;35:55-61.

18. Torres P, Ramos M, Carrasco L, Neumann M, Franjola R, Navarrete N. Protozoos, helmintos y artrópodos del perro doméstico en la ciudad de Valdivia, Chile. Bol Chil Parasitol. 1974;29:18-23.

19. Torres P, Hott A, Boehmwald H. Protozoos, helmintos y artrópodos en gatos de la ciudad de Valdivia y su importancia para el hombre. Arch Med Vet. 1972;4:20-9.

20. Anaruma Filho F, Chieffi PP, Correa CR, Camargo ED, Silveira EP, Aranha JJ, et al Human toxocariasis: a seroepidemiological survey in the municipality of Campinas (SP), Brazil. Rev Inst Med Trop Sao Paulo. 2002;44:303-7.

21. Cancrini G, Bartolini A, Zaffaroni E, Guglielmetti P, Gamboa H, Nicoletti A, et al. Seroprevalence of Toxocara canis-IgG antibodies in two rural Bolivian communities. Parassitologia. 1998;40:473-5.

22. Chiodo P, Basualdo J, Ciarmela L, Pezzani B, Apezteguía M, Minvielle M. Related factors to human toxocariasis in a rural community of Argentina. Mem Inst Oswaldo Cruz. 2006;101:397-400

23. Dogan N, Dinleyici EC, Bor O, Töz SO, Ozbel Y. Seroepidemiological survey for Toxocara canis infection in the northwestern part of Turkey. Turkiye Parazitol Derg. 2007;31:288-91

24. Roldán WR, Espinoza YA, Huapaya PE, Huiza AF, Sevilla CR, Jiménez S. Frequency of human toxocariasis in a rural population from Cajamarca, Peru determined by DOT-ELISA test. Rev Inst Med Trop Sao Paulo. 2009;51:67-71. 
Vargas C, Torres P, Jercic MI, Lobos M, Oyarce A, Miranda JC, Ayala S. Frequency of anti-Toxocara spp. antibodies in individuals attended by the Centro de Salud Familiar and environmental contamination with Toxocara canis eggs in dog feces, in the coastal Niebla town, Chile. Rev Inst Med Trop Sao Paulo. 2016;58:62.

25. Herrmann N, Glickman LT, Schantz PM, Weston MG, Domansk LM. Seroprevalence of zoonotic toxocariasis in the United States: 1971-1973. Am J Epidemiol. $1985 ; 122: 890-6$

26. Chieffi PP, Ueda M, Camargo ED, de Souza AM, Leopoldo e Silva C, Villa Nova A, et al. Contacto domiciliar e profissional com cães como fatores de risco para infecção humana por larvas de Toxocara. Rev Inst Med Trop Sao Paulo. 1988;30:379-82.

27. Altcheh J, Nallar N, Conca M, Biancard M, Freilij H. Toxocariasis: aspectos clínicos y de laboratorio en 54 pacientes. An Pediatr (Barc). 2003;58:425-31.

28. Roldán WH, Espinoza YA, Atúncar A, Ortega E, Martínez A, Saravia M. Frequency of eosinophilia and risk factors and their association with Toxocara infection in schoolchildren during a health survey in the north of Lima, Perú. Rev Inst Med Trop Sao Paulo. 2008;50:273-8.

29. Chile. Instituto Nacional de Estadísticas. Censo 2002 : síntesis de resultados. [cited 2016 Mar 15]. Available from: http://www.ine.cl/cd2002/sintesiscensal.pdf

30. Ruiz-Argüelles G, Ruiz Reyes G, Ruiz Delgado G. Interpretación de la citometría hemática. Índices y parámetros eritrocíticos. Definición de anemia. In: Ruiz-Argüelles G, editor. Fundamentos de hematología. $4^{\text {a }}$ ed. México: Médica Panamericana; 2009.

31. Vives Corrons J, Aguilar Bascompte JL. Manual de técnicas de laboratorio en hematología. $3^{\text {a }}$ ed. Barcelona: Masson; 2006.

32. Clinical and Laboratory Standards Institute. User protocol for evaluation of qualitative test performance: approved guideline. $2^{\mathrm{a}}$ ed. Pennsylvania: CLSI; 2008. (EP12-A2)

33. Clinical and Laboratory Standards Institute. Verificación del desempeño de la precisión y veracidad por el usuario. $2^{\mathrm{a}}$ ed. Pennsylvania: CLSI; 2005. (EP15-A2)

34. Knight WB, Hiatt RA, Claine BL, Ritchie LS. A modification of the formol-ether concentration technique for increased sensitivity in detecting Schistosoma mansoni eggs. Am J Trop Med Hyg. 1976;25:818-23.

35. Zar JH. Biostatistical analysis. $4^{\text {th }}$ ed. Upper Saddle River: Prentice-Hall; 1999.

36. Astorga B, Briceño E, Jorquera H, Herskovic P. Perfil parasitológico en habitantes de la Isla Robinson Crusoe. Parasitol Día. 1988;12:176-81.
37. Delgado O, Rodriguez-Morales AJ. Aspectos clínico-epidemiológicos de la toxocariasis: una enfermedad desatendida en Venezuela y América Latina. Bol Malariol Salud Amb. 2009;49:1-33.

38. Maizels RM. Toxocara canis: molecular basis of immune recognition and evasion. Vet Parasitol. 2013;193:365-74.

39. Agudelo C, Villarreal E, Cáceres E, López C, Eljach J, Ramírez N, et al. Human and dogs Toxocara canis infection in a poor neighborhood in Bogotá. Mem Inst Oswaldo Cruz. 1990;85:75-8

40. Rubinsky-Elefant G, da Silva-Nunes M, Malafronte RS, Muniz PT, Ferreira MU. Human toxocariasis in rural Brazilian Amazonia: seroprevalence, risk factors, and spatial distribution. Am J Trop Med Hyg. 2008;79:93-8

41. Teixeira CR, Chieffi PP, Lescano SA, de Melo Silva EO, Fux B, Cury MC. Frequency and risk factors for toxocariasis in children from a pediatric outpatient center in southeastern Brazil. Rev Inst Med Trop Sao Paulo. 2006;48:251-5.

42. Gawor J, Borecka A, Zarnowska H, Marczynska M, Dobosz S. Environmental and personal risk factors for toxocariasis in children with diagnosed disease in urban and rura areas of central Poland. Vet Parasitol. 2008;155:217-22.

43. Oberg C, Franjola R, Leyán V. Helmintos del perro doméstico (Canis familiaris), en la ciudad de Valdivia, Chile. Bol Chil Parasitol. 1979;34:21-6.

44. Negri EC, Santarém VA, Rubinsky-Elefant G, Giuffrida R. Anti-Toxocara spp. antibodies in an adult healthy population: serosurvey and risk factors in Southeast Brazil. Asian Pac J Trop Biomed. 2013;3:211-6.

45. Triviño X, Bedregal P, Torres M, Canales M, Alvarado C, Hernández R. Toxocarosis en Chile: serie clínica en un centro de pediatría ambulatoria. Parasitol Día. 1999;23:113-

46. Mendoza Meza DL, Lozano Socarras S, Jaimes MB. Exposición al parásito Toxocara canis en un población escolar de la comuna 7 del distrito de Santa Marta, Colombia. Duazary. 2010;7:183-90

Received: 04 December 2015

Accepted: 15 March 2016 